\title{
pÿBusiness in the Battle of Ideas, 19451991 : Conclusions from the Finnish Case
}

\section{Wuokko, Maiju}

2017-11

pÿWuokko , M 2017 , ' Business in the Battle of Ideas, 19451991 : Conclusions from the

Finnish Case ' , Scandinavian Economic History Review , vol. 65 , no. 3 , pp. 279-293 . https://doi.org/10.1080/03585

http://hdl.handle.net/10138/232062

https://doi.org/10.1080/03585522.2017.1371638

acceptedVersion

Downloaded from Helda, University of Helsinki institutional repository.

This is an electronic reprint of the original article.

This reprint may differ from the original in pagination and typographic detail.

Please cite the original version. 


\section{Business in the Battle of Ideas, 1945-1991: Conclusions from the Finnish Case}

Maiju Wuokko

Department of Philosophy, History, Culture and Art Studies, University of Helsinki, Helsinki, Finland

P.O. Box 59

00014 University of Helsinki

$+358456399363$

maiju.wuokko@helsinki.fi

ORCID: 0000-0002-2536-2505

Maiju Wuokko is a Finnish PhD and a 'political business historian' specialising in businesspolitics-links, business associations, and employer policies. 


\section{Business in the Battle of Ideas, 1945-1991: Conclusions from the Finnish Case}

Acknowledgements: I wish to thank Professor Niklas Jensen-Eriksen, Petteri Jakku, the anonymous reviewers, and all those who at various conferences commented on the earlier drafts of this paper.

This article examines the political activity—specifically lobbying and PR efforts — of major Finnish business associations during the Cold War era (c. 1945-1991). The main motivation for business political activity was the threat of socialism and state intervention in their various forms. Based on a qualitative reading of archived documents, this article illustrates a shift from the fear of an outright revolution in the 1940s, through leftist radicalism and economic regulation in the 1970s, to the rise of environmentalism in the 1980s. Influencing efforts were targeted at both politicians and the general public but, towards the end of period studies, shaping public opinion became increasingly important. This article contributes to our knowledge on business-politics links and business political activity as historical phenomena. It points out compelling similarities in the political activity of business in various Western countries and suggests that they should be examined more thoroughly in future research.

Keywords: business political activity, corporate political activity, business interest associations, lobbying, public opinion

E61, E66, N44, P16

\section{Introduction}

The Cold War (approximately 1945-1991) between the Communist East and the Capitalist West was paralleled by another struggle fought within the Western countries. The latter struggle was a contest of economic interventionism against free markets. Economist Friedrich Hayek had first declared this 'war of ideas' after World War II when he summoned like-minded thinkers to join forces in defence of free market capitalism and against socialism and statism (Hayek, 1949; see also Stedman Jones, 
2014). For Hayek and his mentor, Ludvig von Mises, this battle was crucial. According to Mises, 'the outcome of the intellectual combat between the supporters of Socialism and those of Capitalism' would decide 'the fate of the West' (quoted by Phillips-Fein, 2009, p. 40).

The Hayekian battle of ideas was resolved simultaneously with the Cold War at the turn of the 1990s when the Soviet Union collapsed. Socialism and statism suffered a defeat in both contests. During the Cold War era, however, the outcome was far from self-evident. On the contrary, faith in the advantages of economic and social planning was strong throughout the West.

Political fluctuations were reflected in the operational preconditions of private enterprises. State intervention led to increasing business regulation, and the construction of welfare systems heightened taxation. From the perspective of business leaders, the question was ultimately about the operational and strategic control over their companies. Private business obviously had a lot at stake. It could not just stand by, but had to take an active part in the defence of the free market economy.

In this paper, I look at the role of business in the battle of ideas by examining the political activity of Finnish 'peak business associations' (cf. Boswell \& Peters, 1998; Stenlås, 2001). What kind of threats did business leaders identify in the political climate of Finland during the Cold War? ${ }^{1}$ How did they fight these threats off, and who was in

${ }^{1}$ A. V. Dicey (1905, pp. 19-20) defines 'political climate' as a 'body of beliefs, convictions, sentiments, accepted principles' which make up the 'dominant current of opinion' at a given time. The concept is somewhat problematic but, nevertheless, my research subjects regarded the political climate as something real and tried to influence it (cf. Denham \& Garnett, 1998). 
charge of the defensive action? Who or what were the targets? How did the threats and preventive strategies evolve during the Cold War decades?

I argue that the main threats were socialism and state intervention in their various forms. Based on a qualitative reading of archival data, I illustrate a shift from the fear of outright revolution and nationalisation in the late 1940s, through the leftist radicalism and increasing economic regulation of the 1970s, to the rise of environmentalism and soft values in the late 1980s. Along with these shifts, the defensive action evolved from sporadic campaigns to professional efforts run by permanent organisations. Throughout the examined decades, these efforts were targeted at both top-level politicians and the general public. Towards the close of the 1980s, however, influencing public opinion became increasingly important as the main target of business associations' political activity.

This article promotes our knowledge of business-politics links and business political activity as historical phenomena. Business efforts to shape public policy have traditionally been an important topic for business historians (see, Kipping, 2003). However, as Neil Rollings (2014, p. 915) has stated regarding Britain, it is 'striking how sparse is recent writing on business and politics' especially concerning the period since 1945. The same seems to be the case, for example, in Sweden. In Finland, a few recent company, industry, and organisation histories (e.g. Jensen-Eriksen, 2007; Koroma, 2015; Kuisma, 2004; Kuisma, 2008) and some specialised studies (e.g. Jensen-Eriksen, 2013; Kärrylä, 2016; Okkonen, 2013; Wuokko, 2013 \& 2016) look at the political activity of business as a central or even as an overriding theme. In the United States, a wave of historical studies on business and politics has emerged in recent years (e.g., John \& Phillips-Fein, 2016; Phillips-Fein, 2009; Phillips-Fein \& Zelizer, 2012; 
Waterhouse, 2014). Still, the topic is by no means exhaustively covered. International and/or comparative perspectives, in particular, are yet to be applied.

The article also draws from research on business political activity, often referred to as corporate political activity (CPA). CPA literature is utilised here as a source of theoretical lenses through which to examine the empirical data. CPA can be defined as 'corporate attempts to shape government policy in ways favourable to the firm' (Hillman, Keim, \& Schuler, 2004, p. 838). Typically, the creation and preservation of competitive advantage are seen as the main objectives of CPA (Lawton, McGuire, \& Rajwani, 2013). However, firms may also use CPA to pursue 'societal benefits', such as stability, legitimacy, and prestige, or to mould the general atmosphere in a manner consistent with corporate (or business) interests (Skippari, 2004, pp. 29-30). The various forms of CPA as listed by Mika Skippari (2004) include, for instance, election funding, petitions to political decision-makers, memberships of legislative committees, lobbying, and advocacy advertising (i.e., efforts to influence public opinion). This paper focuses on the latter two (i.e., lobbying and attempts to mould the general political atmosphere) ${ }^{2}$

Research on CPA usually concentrates on firm-level actors, but some scholars have called for wider perspectives, for instance, studies on business associations (Lawton et al., 2013; Shaffer, 1995). In this paper, I approach 'Finnish business' through the lens of three major business organisations: Suomen Teollisuuden Keskusvaliokunta (STKV; the Central Committee of Finnish Industry), Elinkeinoelämän

\footnotetext{
${ }^{2}$ By 'lobbying', I refer to the establishment and upkeep of contacts with political decisionmakers to provide them with information about business' policy preferences and to shape future policy to the benefit of business (Anastasiadis, 2006).
} 
Valtuuskunta (EVA; the Council of Economic Organisations in Finland), and Teollisuuden Keskusliitto (TKL; the Confederation of Finnish Industries). ${ }^{3}$

The eldest among these business associations was the STKV. The STKV served as an arena for discussion on matters that concerned Finnish industry as a whole (Mansner, 1990). It was founded in 1935 by the representatives of Finnish export and domestic market industries, which were divided in separate associations until they merged to form the TKL in 1975. The TKL was an interest group advocating the interests of all fields of Finnish industry in the realms of economic and industrial policy. EVA, founded in 1974, was not a traditional interest association but a think tank, that is, a policy research and advocacy organisation. Think tanks aim to produce and disseminate information, create public discussion, and provide policy recommendations about issues that they consider significant (McGann, 2007; Rich, 2004).

On the one hand, the examined associations had different functions within the field of business political activity. On the other hand, they were concerned with similar issues and objectives and can, therefore, be studied jointly. It also has to be noted that two out of the three associations studied (namely, the STKV and the TKL) mainly advocated the interests of industry in contrast to EVA, which was established to

\footnotetext{
${ }^{3}$ Within the scope of this article, I am unable to examine Suomen Työnantajain Keskusliitto (STK; the Finnish Employers' Confederation). The exclusion of labour market issues can be justified by the fact that traditionally, business communities have tended to establish two distinct kinds of interest associations, that is, (a) trade associations that deal with general political issues, and (b) employers' associations that specialise in labour market relations (Lanzalaco, 2008). The exclusion is somewhat artificial, since employer policies cannot be formed independently of other political objectives of business. Therefore, I want to encourage the study of these two spheres of business political activity side by side.
} 
represent the whole Finnish business community. Nevertheless, throughout the examined decades, it was precisely these peak organisations that repeatedly discussed the development of the Finnish political climate and took action to defend private enterprise and the free market economy from state intervention. ${ }^{4}$

My interpretation is thus based on the original documents of the aforementioned organisations and their leaders. The collections utilised are: the archive of EVA and the private archives of its founder and first Chairman Päiviö Hetemäki (PH) and first CEO Max Jakobson (MJ) at Kansallisarkisto (KA; the National Archives of Finland) in Helsinki; and the archives of the STKV and the TKL in Elinkeinoelämän Keskusarkisto (ELKA; the Central Archives for Finnish Business Records) at Mikkeli. At the time of collecting the data, part of the TKL's archive was held by Elinkeinoelämän Keskusliitto (EK; the Confederation of Finnish Industries) in Helsinki.

The archival materials consist of confidential internal documents such as minutes of board and executive committee meetings, complemented by memoranda collections and CEOs' correspondence. In addition, the materials include manuscripts for speeches at the associations' spring or autumn meetings and presentations held at various public events, thus directed to wider audiences. I have utilised these sources to

${ }^{4}$ A similar perspective has been recently utilised by Benjamin Waterhouse (2014). This kind of a 'bird's eye view' combined with a relatively long period of study does not allow for detailed depictions of individual actors or single events in an article (however, for more detailed accounts, see Wuokko, 2013 \& 2016). It is a deliberate choice to focus on the wood instead of the trees: By drawing the 'big picture', I am able to highlight the broad development patterns of business political activity in Finland, which then allows tentative comparisons between the Finnish case and other Western countries. 
establish a picture of those political issues and developments that the representatives of Finnish business considered most fundamental during the examined period. It has to be stressed that the sources do not necessarily reveal the 'actual' state of affairs but depict the circumstances as experienced by the leading figures of the Finnish business community.

During the Cold War, Finland was a capitalist democracy and belonged to the group of neutral countries. At the same time, however, the neighbouring Soviet Union tangibly influenced both Finnish domestic and foreign policies. Finnish business was involved in large-scale trade with the Soviet Union, which business leaders had to take into account in their political activity. Caution was called for so as not to irritate the Eastern superpower with daring statements about the evils of socialism and the blessings of capitalism (Wuokko, 2013).

Apart from these considerations, the political pursuits of Finnish business leaders were in line with their colleagues elsewhere in the West. Previous literature on the political activity of business in various Western countries reveals compelling similarities throughout the West during the Cold War decades. Drawing actual comparisons between different countries is problematic because of profound differences in their political systems. ${ }^{5}$ I will, however, point out similarities suggested by a side-byside reading of my empirical data and earlier scholarship on the political fortunes and activities of business in other Western market economies.

\footnotetext{
${ }^{5}$ According to Mark Blyth, who has conducted a comparative study on the United States and Sweden, notable differences actually make the similarities found all the more interesting (Blyth, 2002, p. 262; see also Useem, 1984, pp. 7-8).
} 
This paper is divided into five subsections. The introduction is followed by an examination of the political circumstances in which the business communities in the West, and in Finland in particular, found themselves after World War II. The third and fourth subsection illuminate the developments in the 1970s and the 1980s, respectively. The concluding section draws the findings together and suggests fruitful areas for future research.

\section{The 1940s: Anxiety over the 'Socialisation Issue'}

In virtually all Western countries, World War II strengthened governmental regulation of the economy and improved the clout of the political Left. To organise the wartime economy effectively, governments tightened their grip on the economy through the control of business activities. In addition, the crucial significance of workers' support to the war effort increased the influence of organised labour in national policies.

Furthermore, plans for nationalisation emerged in various countries in Europe in the post-war years. For example, in Great Britain, Clement Attlee's labour government (1945-1951) nationalised certain strategic industries and public utilities (Millward, 1997). France, as well, nationalised banks, coal-mines, and gas and electricity works (Toninelli, 2000). In Sweden, where a compromise between capital and labour had been concluded already before the war in the so-called Saltsjöbaden Agreement in 1938, several social reforms were implemented in the late 1940s in consensus between the political Left and Right (Frenander, 1999). However, a heated debate erupted around the issues of state-directed economic planning and nationalisation (Stenlås, 2001).

Business circles in various countries took action to fight the leftist and statist political trends. For instance, in the United States, the business community launched an aggressive PR campaign targeted against labour unions and government regulation. The 
campaign's rhetoric associated social planning with ‘creeping socialism' and identified interventionist governments and strong unions with oppression. The free-enterprise system, on the other hand, was linked with core American values such as freedom and democracy (Carey, 1995; Fones-Wolf, 1995). In Sweden, likewise, the business community rallied against the Social Democrats' plans to expand state intervention in the economy. In the so-called planhushållningsmotståndet ('planned economy resistance') campaign, economic planning was equated with socialism and dictatorship (Frenander, 1999).

In the United States, a conservative Republican majority was elected to Congress already in 1945, 'dashing hopes for a renewed, post-war New Deal' (Friedman, 2008). All in all, according to Elizabeth Fones-Wolf (1995, p. 3), 'a fullscale mobilisation of business and conservative forces decisively blocked unions from reshaping the post-war political economy along social democratic lines'. Fones-Wolf depicts the 1950s in America as a period of consensus over the priority of economic growth and general understanding over productivity gain-sharing (Fones-Wolf, 1995). Furthermore, the decade was characterised by increasing public suspicion toward governmental regulation (Vogel, 1996).

In most European countries, too, the momentum of the political Left was shortlived. The popularity of Communists, in particular, soon abated and the outbreak of the Cold War pushed them to the margins again. Social Democrats, on the other hand, were able to establish a more permanent foothold by taking the lead in the construction of European welfare systems. While the Social Democrats pushed substantial social reforms, outright revolution was not on their agenda. European welfare states were founded on a combination of state intervention and social security along with capitalism and competitive industrial production. The leftist post-war Zeitgeist gave way to 
conservative, pro-market and pro-capitalist sentiment of the 1950s. Leftist radicalism was cast aside as capitalism seemed better suited to deliver economic growth, full employment, and rising living standards to the Europeans (Eley, 2002; Sassoon, 1997).

Similarly, to the rest of Western Europe, anti-communism strengthened in Sweden toward the close of the 1940s. Swedish Social Democrats abandoned their most radical goals and adopted a 'third way' between capitalism and socialism. The 1950s in Sweden has been characterised in terms of cooperation and consensus. Political and ideological conflicts faded into the background, and the construction of a 'middle-class welfare state' began. (Frenander, 1999; Nycander, 2002).

Virtually in all these respects, Finland followed suit. The war left the Finnish economy state-regulated for decades: Rationing lasted until the mid-1950s and price controls until the 1980s (Pihkala, 1999). Suomen Kommunistinen Puolue (SKP; the Communist Party of Finland) had been underground since its establishment in 1918 but was legalised in 1944. The Communists won a quarter of the seats in the parliamentary elections of 1945 and were welcomed to the cabinet. Finland was not an anomaly: In the first post-war elections, Communists enjoyed unprecedented electoral success across Europe thanks to their pivotal role in resistance movements during the war (Sassoon, 1997).

Naturally, this development was unappealing to Finnish business leaders. Their anxiety was markedly aggravated by the neighbouring Soviet Union. During the postwar period of 1944-1948, often called 'the years of danger', many non-socialists were afraid that Finland would turn into a Communist country through a Soviet occupation or a leftist coup. While the threat of a downright revolution soon waned, the prospect of 'creeping socialism' through legislation still remained plausible. (Jensen-Eriksen, 2013; Pihkala, 1999). 
In February 1946, the Finnish government constituted a 'Socialisation Committee'. Its task was to plan the nationalisation of suitable industries or other ways in which government influence over business could be increased. Even according to some members representing the political Left, the actual purpose of the committee was to bury the issue in piles of paper. Nevertheless, the Finnish business community took the threat seriously. The sense of an alarming situation led to emphatic calls for closer cooperation between different fields of business. Visions of a new advocacy organisation that would have represented all branches of business almost took off but were, ultimately, frustrated by the withdrawal of the primary candidate for the new organ's CEO. ${ }^{6}$

The Central Committee of Finnish Industry (STKV) still felt an urgent need for pro-industry PR and decided to continue developing industry's education and information activities without the financial contribution of other fields of business. ${ }^{7}$ The 'socialisation issue', in particular, was repeatedly discussed by the STKV. It launched a counter-attack, which included the founding of an anti-nationalisation fund and the establishment of a research institute with the task of producing pro-business propaganda. In the following years, the institute flooded newspapers with materials that

${ }^{6}$ ELKA, STKV, Minutes of the STKV, STKV meetings 3 May 1945, 25 August 1945, 7 February 1946, and 9 March 1946.

${ }^{7}$ ELKA, STKV, Minutes of the STKV, STKV meetings 9 March 1946, 9 May 1946, 12 November 1946, and 21 January 1947. 
warned the general public about the dangers of nationalisation to the country and its economy (Jensen-Eriksen, 2013; Mansner, 1984). ${ }^{8}$

Already in the 1930s, the STKV had repeatedly discussed the need to intensify the propaganda — in later decades, called more discretely 'economic education and information'-efforts of industry through the press, radio, and the cinema. First of all, the Committee had felt it necessary to remind the general public about the focal role of private enterprise in creating economic and social welfare. Second, the STKV had wanted to prevent the political Left from gaining the majority of seats in Parliament. ${ }^{9}$ The latter objective translated, in practice, into election funding directed at non-socialist parties. These fundamental goals remained unchanged in the 1940s — and, in fact, throughout the Cold War decades as this article illustrates. As the STKV saw it, these two avenues of influence — the 'party-political line' and the 'press line'-were distinct but closely related, and both equally significant. ${ }^{10}$

Like elsewhere in the West, the Finnish political climate calmed down fairly fast. The post-war 'years of danger' passed without the Communists ever even attempting a coup. One of the main reasons was that the Soviet Union never really pressured the Finnish Communists to do so. The Soviets benefited more from a

${ }^{8}$ ELKA, STKV, Minutes of the STKV, STKV meetings 14 February 1945, 12 November 1946, 12 December 1946, 17 February 1947, and 19 March 1947.

${ }^{9}$ ELKA, STKV, Minutes of the STKV, STKV meetings 29 November 1937 and 14 January 1938.

${ }^{10}$ ELKA, STKV, Minutes of the STKV, STKV meetings 17 February 1947 and 28 August 1947. 
capitalist Finland which was able to supply the Soviet Union with goods, first as war reparations and later through bilateral trade.

The nation focused on reconstruction, and social unrest quieted down. As the political situation stabilised, Finnish industry leaders' dedication to the intense influencing efforts waned. STKV members became increasingly reluctant to fund the research institute that had been established a few years earlier. ${ }^{11}$ In the 1940 s, the STKV had felt that there was no alternative to large-scale lobbying and PR campaigns. The next decade, the STKV stated that politics 'as such' did not belong to the domain of the Committee. ${ }^{12}$ The STKV should only intervene in issues that directly affected industry. ${ }^{13}$ The development was comparable to Sweden, where business adopted a lower political profile and discontinued the aggressive campaign that had been initiated in the 1940s (Boréus, 1994; Stenlås, 2001).

At the turn of the 1950s, the immediate post-war challenges to the economic system had thus passed in Finland, and the most radical leftist reform plans had been effectively watered down. Instead of turning Finland into a communist country, the 'years of danger' set the country on a path toward a Nordic welfare state with increasing wage levels and an incipient social security programme (Jensen-Eriksen, 2013). For the next couple of decades, the challenge to private enterprise came in the form of an expanding social welfare system and increasing public spending rather than outright communism and the nationalisation of companies.

${ }^{11}$ ELKA, STKV, Minutes of the STKV, STKV meetings 13 January 1949, 10 January 1952, 19 October 1955, 4 October 1956, and 20 November 1957.

${ }^{12}$ ELKA, STKV, Minutes of the STKV, STKV meeting 15 May 1950.

${ }^{13}$ ELKA, STKV, Minutes of the STKV, STKV meeting 20 October 1954. 


\section{The 1970s: Business under Attack}

After the relative calm of the 1950s, the next round in the battle of ideas came in the late 1960s and early 1970s. For instance, in the United States, the prosperous American consensus of the 1950s was challenged in the latter part of the 1960s. Many American liberals wanted to turn the United States into a European-style welfare state. While the most radical visions never materialised, social welfare expenditures nevertheless increased and regulation expanded in matters such as pollution, workers' health, and product safety. (Carey, 1995; Micklethwait \& Wooldridge, 2004; Smith, 2000; Vogel, 1989).

Furthermore, attitudes toward private business became increasingly negative. Suddenly, corporations had to run the gauntlet of boycotts and exposés. Protests came as a shocking surprise to American business leaders and made them feel politically vulnerable. Some even feared that increasing regulation pointed down the path of de facto nationalisation. According to the gloomiest prophecies, the American society was about to collapse under a socialist dictatorship. (Carey, 1995; Smith, 2000; Vogel, 1989; Vogel, 1996; Useem, 1984).

Across the Atlantic, the political influence of business eroded in a similar fashion (Blyth, 2002, Vogel, 1996). For instance, British businessmen were haunted by the spectre of socialism. It appeared in the shape of the increasingly powerful Labour Party and trade union movement with their demands for the nationalisation of banks and insurance companies. (Useem, 1984). Large-scale strikes hit several countries in Western Europe (Sassoon, 1997). Labour market unrest increased and ideological polarisation grew in Sweden, too. The political Left captured the initiative and 
dominated the agenda of Swedish public discussion. (Frenander, 1999; Nycander, 2002).

Similar to the post-war era, business communities throughout the Western countries mobilised their troops against the wave of leftist sentiment. New business associations were established and old interest groups revitalised in order to intensify the political lobbying and the PR efforts of business. (Blyth, 2002; Boréus, 1994; Frenander, 1999; Useem, 1984; Waterhouse, 2014). They launched extensive campaigns to 'reshape the prevailing political and intellectual climate of opinion' (Vogel, 1989, p. 193) and to create 'good-will toward private business' (Nycander, 2002, p. 348). In addition, they began to speak out for more liberal economic policies and brought forward the positive role that private business played in the national economies (Boswell \& Peters, 1997; Nycander, 2002).

Furthermore, business leaders began to give substantial funding to think tanks, which helped to promote pro-business, pro-market, and anti-regulation ideas in public debate (McGann, 2007; Smith, 2000; Vogel, 1989). In the United States, the most notable business-funded think tank was (and is) the Heritage Foundation, founded in 1973. The Hoover Institute and the American Enterprise Institute had existed before but were reinvigorated in the 1970s (Blyth, 2002; Micklethwait \& Wooldridge, 2004; Vogel, 1989). In the United Kingdom, funding from business circles resulted in the establishment of the Adam Smith Institute and the Centre for Policy Studies (Mitchell, 1997). In Sweden, Studieförbundet Näringsliv och Samhälle (SNS, Centre for Business and Policy Studies) was revitalised and a free market think tank called Timbro was founded in 1978 (Blyth, 2002; Boréus, 1994).

In Finland, as well, the climate of ideas became very leftist-oriented by the early 1970s. A hard-left, pro-Soviet movement loudly criticised private business and called 
for its nationalisation. The Social Democratic Party radicalised and adopted hard-line socialist rhetoric. Finnish business leaders felt that hostility to business was not restricted to the political left but that public opinion on the whole-civil servants and politicians included — was increasingly critical toward business. ${ }^{14}$ Executives found the media blatantly leftist-coloured and suspected that the school system, from kindergartens to universities, was teaching dubious attitudes to the young. ${ }^{15}$ In their view, anti-business sentiments had reached such heights that the very social order was at risk. ${ }^{16}$

Simultaneously, state intervention increased to an extent that seemed to threaten the existence of a free economy. ${ }^{17}$ The representatives of industry felt that economic

${ }^{14}$ KA, EVA, Minutes of EVA, Meeting of EVA 4 December 1974, review by Max Jakobson; KA, EVA, Presentations 1973-1984, Kari Nars: 'Yrityksen yhteiskunnallinen tulevaisuus', 4 October 1976.

${ }^{15} \mathrm{KA}$, EVA, Minutes of EVA, Max Jakobson: 'EVA:n repliikki tulevaa rooliaan koskevassa keskustelussa', 24 March 1975; KA, PH, EVA 1973-1978, Stig Hästö to Max Jakobson, 15 October 1976 and attachment 'Eva ja sen rooli'.

${ }^{16}$ KA, EVA, Memoranda 1973-1976, 'Elinkeinoelämän ideologiaa', 6 May 1976; KA, EVA, Minutes of EVA, Memorandum on the discussion at spring meeting dinner 10 June 1976; KA, EVA, CEO Max Jakobson 1975-1980, Max Jakobson: 'Suomen talouselämän linjanvetoa', 6 June 1976.

${ }^{17} \mathrm{KA}, \mathrm{EVA}$, Minutes of EVA, Max Jakobson: 'EVA:n repliikki tulevaa rooliaan koskevassa keskustelussa', 24 March 1975; KA, EVA, Memoranda 1973-1976, 'Elinkeinoelämän ideologiaa', 6 May 1976. 
policies were guided by 'regulation mentality and emergency law hysteria'. ${ }^{18}$ In the opinion of business leaders, Finland was on a slippery slope to a controlled or command economy. At the end of the road loomed the nationalisation of private corporations or even an outright revolution. Executives were bewildered and feared that the whole society might stumble and collapse. ${ }^{19}$

Identical to their colleagues elsewhere in the West, Finnish business leaders mobilised a counter-attack. Through economic education in the press, radio, and television, business leaders hoped to counter the hostile attitudes and to increase public recognition of business as the creator of economic well-being. ${ }^{20}$ Politicians, on the other hand, had to be convinced of the need for 'reasonable' — that is, business-friendly — economic policies. ${ }^{21}$

The merger of the previously separate federations of export and domesticmarket industries into the Confederation of Finnish Industries (TKL) in 1975 was, in part, motivated by the desire to increase the political strength of Finnish industry

${ }^{18}$ ELKA, Teollisuuden Keskusliitto (TKL), Spring and autumn meetings, Spring meeting 20 May 1976, Speech by Chairman Gay Ehrnrooth.

${ }^{19}$ KA, EVA, Memoranda 1973-1976, 'Elinkeinoelämän ideologiaa', 6 May 1976; KA, EVA, CEO Max Jakobson 1975-1980, Max Jakobson: ‘Suomen talouselämän linjanvetoa’, 6 June 1976; KA, EVA, Minutes of EVA, Memorandum on the discussion at spring meeting dinner 10 June 1976.

${ }^{20}$ ELKA, STKV, Minutes of the STKV, STKV meeting 27 November 1970; ELKA, STKV, Minutes of the Delegation of Finnish Industry, Delegation meeting 7 December 1970.

${ }^{21}$ KA, PH, Speeches and drafts, 1972-1975, Hetemäki’s interview for Teollisuuslehti 12/1974; ELKA, STKV, Minutes of the STKV, STKV meeting 31 January 1974 and attachment 'PM Elinkeinoelämän yhteistoiminnan tehostaminen'. 
(Koroma, 2015). Only as a united front — as industry leaders saw it — could they form a counterforce to state intervention and the growing clout of labour unions. ${ }^{22}$ In addition, seven interest associations representing different fields of business established the Council of Economic Organisations in Finland (EVA) in 1974. Although the concept was unfamiliar in Finland at the time, EVA was an exemplary think tank: It conducted research and took part in public debate, actively advocating a pro-business stand. ${ }^{23}$ EVA's main goals were to create a business-friendly general atmosphere and to establish closer contacts between business leaders and politicians. ${ }^{24}$ At bottom, founding EVA was about mobilising into 'action in defence of the existing economic and social order' ${ }^{25}$

${ }^{22}$ ELKA, STKV, Minutes of the STKV, STKV meeting 27 November 1970, Lauri Kirves \& Sakari T. Lehto: 'Lausunto teollisuuden keskusjärjestöjen yhteistyön parantamisesta', 16 June 1970.

${ }^{23}$ EVA is currently known in English as the 'Finnish Business and Policy Forum EVA'. It declares upfront to be 'a policy and pro-market think tank financed by the Finnish business community'. EVA's web page, http://www.eva.fi/en/eva/ (retrieved 15 June 2017). Think tanks have not become a notable part of the Finnish organisational landscape apart from a few others that have been established since the founding of EVA (Kervinen, 2006, 7).

${ }^{24}$ KA, PH, Speeches and manuscripts 1972-1975, Päiviö Hetemäki: 'PM elinkeinoelämän yhteistoiminnan tehostamisesta', 28 December 1973; ELKA, STKV, Minutes of the STKV, STKV meeting 31 January 1974 and attachment 'PM Elinkeinoelämän yhteistoiminnan tehostaminen'.

${ }^{25}$ ELKA, STK, Minutes of the STK's board, STK board meetings 28 March 1974 and 21 May 1974. 
While the business community in principle stood united behind EVA's core objective, the Council soon ended up in somewhat surprising quarrels with the TKL. While EVA was supposed to defend the market economy system, industry leaders did not want EVA to make too much noise about it. Their caution was caused by large-scale trade between Finland and the Soviet Union, which was of notable significance to Finnish industry despite the bulk of Finnish exports going to the West. ${ }^{26}$ The executives of industry feared that loud statements about the blessings of capitalism and the evils of socialism might irritate the Soviet Union and thus affect the trade relations negatively (in more detail, see Wuokko, 2013). The 'eastern-political' caution of industry leaders was a special feature in the political activity of Finnish business during the Cold War era, which otherwise followed a similar pattern as elsewhere in the West.

Further controversy flared up about the division of labour between EVA and the TKL. In principle, their tasks differed from each other: EVA was supposed to be a visionary thought leader defending long-term business interests, while the TKL concentrated on day-to-day politics. In practice, however, EVA and the TKL were interested in similar activities, and both wanted to act as the main voice of the Finnish business community. (Wuokko, 2013; Wuokko, 2016). The two organisations trampled on each other's toes, especially when it came to establishing contacts with leading politicians. ${ }^{27}$ The TKL accused EVA of wasting resources by creating overlapping

${ }^{26}$ On the somewhat under-researched Finnish-Soviet trade in English, see, e.g., Eloranta \& Ojala, 2005; Möttölä, Bykov, \& Korolev, 1983; Paavonen, 2005; Sutela, 2005.

${ }^{27}$ KA, PH, Elinkeinoelämän valtuuskunta 1973-1978, Mika Tiivola to Hetemäki, 10 May 1977; KA, EVA, Correspondence, Max Jakobson to Stig Hästö, 15 April 1977; ELKA, TKL, Spring and autumn meetings, Autumn meeting 30 November 1977, Timo Laatunen's report. 
functions. ${ }^{28}$ Business executives were, naturally, reluctant to provide funding for overlapping organisations, although they considered the intensified PR and lobbying efforts crucial as such. The reluctance only grew in the 1980s, when the general political climate became increasingly favourable to private business and the market economy system.

\section{The 1980s: Environmentalism as a New Threat}

At the close of the 1970s and in the early 1980s, the Western world turned from Left to Right and from statism to market logic. In the United States, the political pendulum shifted from big-government liberalism to conservatism. According to David Vogel (1989, p. 225; see also Smith, 2000, pp. 192-194), the shift was at least in part thanks to the conservative, business-funded think tanks that were able to bring business-friendly policies such as economic deregulation to the forefront of the domestic policy agenda. Paradoxically, downward trade cycles lent further help to the cause. The post-war economic boom ended with the first oil crisis in the early 1970s, and the U.S. economy declined. In the eyes of the public, business now appeared vulnerable and, therefore, worthy of support, which increased the power of business in American politics. (Vogel, 1989).

The economic recession of the 1970s was by no means limited to the United States, because the oil crisis affected all major industrial countries. In Western Europe,

${ }^{28}$ E.g. ELKA, STKV, Minutes of the STKV, STKV meeting 20 October 1975; KA, PH, Elinkeinoelämän valtuuskunta 1973-1978, Stig Hästö to Max Jakobson 15 October 1976, attachment PM 'EVA ja sen rooli’ and Mika Tiivola to Päiviö Hetemäki 10 May 1977, attachment Stig Hästö: PM ‘EVA:n synty ja kehitys’, 25 April 1977. 
the 'Golden Age' of post-World War II economic growth came to an end. In this setting, ideas that emphasised the benefits of free market forces and the disadvantages of state intervention gained ground. The most obvious signs of the international trend were the election of Margaret Thatcher as Prime Minister of the United Kingdom in 1979 and Ronald Reagan as President of the United States in 1980. The key goals of the Thatcher and Reagan governments included restricting the economic role of the state, deregulating the economy, promoting free competition, and liberating financial markets. These reforms were well in line with the political agenda of business. ${ }^{29}$

Even outside the Anglo-American world, similar ideas triumphed. While in the 1970s, Sweden had been dominated by the political Left, the 1980s was characterised by a 'rightist tide'. In contrast to the previous decade, private enterprise was now seen in an increasingly positive light. The public sector and high taxation, on the other hand, were more and more often attributed negatively as a burden. (Boréus, 1994; Frenander, 1999).

On the other hand, new clouds gathered on the horizon of business circles in the form of environmentalism and Green parties. Erosion in the popularity of leftist ideas and the Soviet Union's might turned the attention of Western business communities from the 'Red Scare' of communism to the 'Green Scare' of the environmental movement (Jacques, Dunlap, \& Freeman, 2008, pp. 352, 362). For instance, in Sweden,

${ }^{29}$ However, the relationship of the British and American business communities with the Thatcher and Reagan administrations was ambiguous because, despite the pro-business political overtones, business leaders were not always happy with their actual policy choices (in more detail, see, Boswell \& Peters, 1997, 142-159; Phillips-Fein, 2009, 261-262; Useem, 1984, 170, 192; Waterhouse, 2014, 228). 
environmental issues had already been put on the public agenda in the 1970s, but their weight increased markedly during the 1980s. Environmentalism became a new ideological alternative to the traditional options of capitalism and socialism (Frenander, 1999).

This development seems to have gone hand in hand with another shift in business political activity. As Doris Fuchs (2007) has noted, business interest associations have spent growing amounts of resources on shaping the agenda of public discussion since the 1970s. In Sweden, for example, the business community turned its attention from influencing political decision-making to shaping the public debate (Boréus, 1994). The development is in unison with the more general trend of political power becoming dependent on mass media. According to Jill McCluskey and Johan Swinnen (2010, p. 644), this is aptly illustrated by the fact that the 'first target of a military coup or a popular uprising is no longer the police station, but the television station'.

Yet again, developments in Finland followed a similar pattern. By the early 1980s, the socialist scare was a thing of the past there, too. The threat of nationalisation, let alone revolution, was effectively watered down by a decline in the attractiveness of socialist ideas. According to EVA, the 'invigorating and revitalising effect' of market forces was widely acknowledged. ${ }^{30}$ Contrary to the 1970 s, when private enterprise had been harshly mocked—rejoiced EVA—-pro-business attitudes now defined the general

\footnotetext{
${ }^{30}$ KA, EVA, Minutes of EVA, Autumn meeting 12 December 1988, Opening speech by Chairman Mika Tiivola.
} 
atmosphere. ${ }^{31}$ It seemed that the shift in sentiment was also mirrored in the field of politics, where decision makers at both ends of the political spectrum had become more sympathetic to business and its claims. And it was not just attitudes that changed. Actual economic policies, too, became increasingly market- and competition-oriented. As the representatives of business saw it, the importance of pro-business goals such as competitiveness and productivity had become self-evident to politicians. ${ }^{32}$

While the development was favourable to business, it also spelt challenges for business associations. Now that the most pressing threats to private enterprise had passed, it became increasingly difficult for EVA and the TKL to convince their members to keep funding their existence (cf. Lamberg, 1999, p. 30). ${ }^{33}$ Instead of starting a new turf war, perhaps somewhat surprisingly, EVA and the TKL managed to

${ }^{31}$ KA, EVA, CEO Kauko Sipponen, 1987-1988, e.g. Kauko Sipponen: ‘Suomen mielipideilmasto', 19 March 1987; KA, EVA, Minutes of EVA, Autumn meeting 12 December 1988, Opening speech by Chairman Mika Tiivola; ELKA, STKV, Minutes of the STKV, STKV meeting 1 September 1987.

${ }^{32}$ ELKA, STK, Minutes of the STK's board, STK board meeting 24 September 1987; ELKA, TKL, Spring and autumn meetings, Autumn meeting 26 November 1987, 'Teollisuuden Keskusliiton tehtävät ja toiminta 80-luvulla'; KA, EVA, Minutes of EVA, Autumn meeting 12 December 1988, Opening speech by Chairman Mika Tiivola.

${ }^{33}$ ELKA, TKL, Spring and autumn meetings, Autumn meeting 26 November 1987, 'Teollisuuden keskusliiton tehtävät ja toiminta 80-luvulla', and Spring meeting 25 May 1988, Timo Relander's report; KA, EVA, Minutes of EVA, Spring meeting 23 May 1988, and Kauko Sipponen 1987-1988, interview for Optio magazine, 29 November 1988. 
develop a working division of labour. EVA retained the role of a visionary while the TKL focused on its core expertise in economic, industrial, and trade policies. ${ }^{34}$ To justify their raison d'être, EVA and the TKL turned their attention to rising political phenomena that were potentially threatening to business interests. EVA warned that although free market ideology was prevailing, the business community should not be lulled into thinking that the danger of collectivism had passed for good. ${ }^{35} \mathrm{New}$ threats arose in the form of 'populist single-issue groups' such as the environmental movement. ${ }^{36}$ Anti-growth, anti-technology, and anti-nuclear 'soft values' posed an ideological challenge to the market economy just like leftism had done in the previous decade. ${ }^{37}$ State intervention pushed in the name of environmentalism was just as disastrous for private enterprise as the statist ambitions of the political Left (Tarkka, 2002). ${ }^{38}$

${ }^{34}$ KA, EVA, Minutes of EVA, Meetings of EVA's executive committee 8 February 1985, 21 May 1986, 19 April 1989, 14 September 1989, and 25 April 1990; ELKA, TKL, Spring and autumn meetings, Autumn meeting 26 November 1987, 'Teollisuuden keskusliiton tehtävät ja toiminta 80-luvulla', and Spring meeting 25 May 1988, Timo Relander's report.

${ }^{35}$ KA, EVA, Minutes of EVA, Meeting of EVA's executive committee 19 April 1989, Kauko Sipponen: 'EVAn toiminnasta 1990-luvulla'.

${ }^{36}$ EK, TKL, Minutes of the TKL, TKL board meeting 16 October 1980, attachment 'Teollisuuden Keskusliiton toimintasuunnitelma 1981'.

${ }^{37}$ KA, EVA, Minutes of EVA, EVA's executive committee meeting 2 November 1981, 'Yhteiskunnallisen tilanteen erityispiirteitä'.

${ }^{38}$ KA, EVA, Kauko Sipponen 1977-1990, PM ‘EVA:n tehtävistä’, Autumn meeting 19 December 1983, and Minutes of EVA, Speech by Mika Tiivola at 'EVA day', 26 October 
The Green threat was, however, far less dramatic than the previous one. As a telling example, Finnish business leaders no longer talked about how to prevent the nationalisation of private business or a socialist revolution like in the 1940s and 1970s. Instead, they discussed, for instance the funding of a Finnish science centre as an integral part of a pro-industry PR campaign. ${ }^{39}$

In the 1980s, the peak organisations of Finnish business indeed attached greater significance to PR than ever before. The strategy of pressuring politicians directly lost relative importance to shaping the public opinion. ${ }^{40}$ It seemed that the general political line followed in Finland converged, by and large, with pro-business and free-market values. Now that politicians from Left to Right all gave their support or at least acceptance to the market economy system, the need to educate decision makers about the perils of state intervention and socialism abated. Instead, business needed to focus on the general climate of ideas and ensure its favourable development (cf. Wilson \& Grant, 2010).

Besides, the representatives of business felt that public attitudes were becoming increasingly decisive when it came to policy-making. According to EVA, the influence of public opinion on politicians and civil servants was on the rise. Thus, business' traditional model of influencing through lobbying and 'cabinet politics' might soon

1988; ELKA, TKL, Spring and autumn meetings, Spring meeting 25 May 1988, Timo Relander's report.

${ }^{39}$ EK, TKL, Minutes of the TKL, TKL board meeting 14 February 1985.

${ }^{40}$ EK, TKL, Minutes of the TKL, TKL board meeting 14 October 1982; KA, MJ, TKL 19861991, Max Jakobson: 'Poliittisen vaikuttamisen kanavat ja keinot muuttuneessa yhteiskunnallisessa tilanteessa', at STKV meeting 1 September 1987. 
prove ineffective. In the future, predicted EVA, all policy issues would be debated in public, and business had to be able to contribute by providing alternatives, arguments, and analyses on the issues at hand. ${ }^{41}$

In Finland, the breakthrough of business interests in politics was sealed by a deep economic recession in the early 1990s. The severity of the slump helped to justify the necessity of pro-business reforms, such as the deregulation of the economy and public sector cuts, which have continued even after the economy recovered. Most West European welfare states have gone through a similar reform period from the 1980s onwards, regardless of the political composition of their governments. (Julkunen, 2001).

\section{Conclusion}

Alongside the Cold War between the capitalist West and socialist East, a parallel battle was fought within the Western countries between statist and free-market ideas. This paper has examined the role of business in this 'battle of ideas' by looking at the political activity of three peak-level business associations in Finland. Focus has been on lobbying and advocacy advertising, that is, attempts to mould the general political atmosphere.

It has been argued that throughout the Cold War decades, the main motive for business political activity was the threat of socialism and state intervention in their

${ }^{41}$ EK, TKL, Minutes of the TKL, TKL board meeting 14 October 1982; KA, EVA, Minutes of EVA, Autumn meeting 19 December 1983, PM ‘EVA:n tehtävistä’; KA, MJ, TKL 19861991, Max Jakobson: 'Poliittisen vaikuttamisen kanavat ja keinot muuttuneessa yhteiskunnallisessa tilanteessa', at STKV meeting 1 September 1987. 
various forms. Three turning points in business political activity have been identified. Immediately after World War II, the strengthening of the political Left made executives concerned about an outright revolution or at least the nationalisation of private business. In the early 1970s, a new wave of leftist sentiment and anti-business attitudes brought back the fear of a revolution. Moreover, business leaders felt that private enterprise was being squeezed to death by expanding state intervention. These anxieties had passed by the 1980s, but new threats emerged in the form of the Green movement and its demands for environmental regulation.

The response of the Finnish business community was to intensify its political activity. The sense of danger led to attempts at centralising the PR and lobbying efforts under the roof of a single association representing Finnish business as a whole. In the 1940s, these attempts were frustrated by the lack of a suitable leader figure — and, probably, by the reluctance of different fields of business to relinquish any of their autonomy (Mansner, 1990, p. 236). In the 1970s, a free-market think tank named EVA was founded as a joint organ of Finnish business but was challenged in this position by the TKL, a newly established interest association of Finnish industry. EVA and the TKL were able to reach a functioning division of labour in the 1980s but, on the other hand, both had to put effort into convincing their members about the need to keep funding their existence.

Throughout the examined decades, Finnish business targeted lobbying and influencing efforts at both politicians and the general public. During the 1980s, however, influencing public opinion became more important. This was due to two converging trends. First, business leaders considered policy-making in general increasingly pro-business and pro-market and no longer felt such a pressing need to 'convert' politicians into proponents of the market economy system. Shaping the 
general climate of ideas thus seemed more worthy of attention. Second, the representatives of business felt that the influence of public opinion on policy-making was on the rise, which emphasised the importance of advocacy advertising in contrast to lobbying.

This article has contributed to our understanding of business political activity as a temporal phenomenon by highlighting its long-term development patterns in Cold War Finland. In addition to presenting the Finnish case, this paper has pointed out apparent similarities in the political activity of business in various Western countries during the Cold War decades (cf. Boréus, 1994, p. 350). The business community of each country naturally strived primarily to influence national-level decision-making. Nevertheless, their agendas coincided on several key issues. Throughout the Western world, business circles gathered their troops in defence of the free market economy. The battle was mainly against the political Left (or, in the United States, liberals), against state intervention in the economy, and against expansive welfare services (Boswell \& Peters, 1997; Vogel, 1989; Waterhouse, 2014).

A special feature in the political activity of Finnish business during the Cold War era was the 'eastern-political' caution of industry leaders. In order to avoid disruptions in the large-scale trade between Finland and the Soviet Union, industry leaders avoided loud statements about issues that could have caused discord between the trading partners. Otherwise, however, the general political trends and business' reactions to them followed a remarkably similar pattern as elsewhere in the West.

Benjamin Waterhouse has stated in passing that ' $[\mathrm{t}]$ he mobilisation of American corporate leaders ... provided a model for European employers' associations, which became increasingly engaged in a market-oriented political project in the 1980s and 1990s and often drew on the rhetorical and organisational strategies that American 
business leaders and their lobbyists pioneered' (Waterhouse, 2014, p. 251). However, the Finnish case presented here suggests that the business communities in Europe mobilised more simultaneously with their American colleagues than Waterhouse suggests.

Our understanding of the political activity of business in the West during the Cold War evidently requires more scholarly attention. In future research, it would be fruitful to both widen and deepen the scope of study. First, we would need more, and more detailed, national-level accounts of business political activity. This would allow us to draw better-grounded comparisons between countries and to judge whether the similarities highlighted here were only superficial or indeed substantive (cf. Stenlås, 2001, p. 283; Useem, 1984, pp. 7-8). If the latter is true, we should take a wider perspective and start looking for explanations for the congruence. What was the role and scope of international links between business communities? How did ideas and influences travel? Can we, in the end, distinguish an international business community that actively and in unison fought for its cause?

This article points to several conclusions relevant for (business) historians and CPA researchers alike. First of all, the Finnish case illustrates how difficult it is for business communities to stay committed to political activity for extended periods of time. The sense of a common enemy may energise business leaders into defensive action but, as soon as the perceived threat abates, the willingness of executives to devote resources to political activity easily wanes. However, once organisations have been set up, they tend to cling to their existence, for instance, by emphasising new threats that require continuous advocacy of business interests.

Second, this article lends support to earlier research that has noted the fragility of business unity (e.g. Vogel, 1989; Waterhouse, 2014). It is easily eroded by turf wars 
and conflicting interests inside the business community, and only the most imminent threats can keep the front united. Third, on a related note, it has to be borne in mind that 'business' cannot be equated with 'industry'. Several internal divisions always prevail within the business community — for instance, between banks and industry, services and manufacturing, importers and exporters, and large and small companies (Wilks, 2013). On the other hand, it is nevertheless important to pay attention to the political activity of 'business' in the singular, as a collective actor. There are, in the end, political core goals such as free market ideas, which bring all branches of business together.

According to social scientists, the political reality of our world is, more than ever, influenced by business actors (e.g., Fuchs, 2007; Wilks, 2013). These claims cry out for historical inquiries into the political activity of business. I would thus like to repeat the wish expressed by Jonathan Boswell and James Peters (1997, p. 197): 'it is to be hoped that in the future ... historians will pay greater attention to the public policy and social ideas of business ...'. We could seek to answer, for instance, how and why the political power of business has varied in the past. Furthermore, it would be useful to assess whether business really is more politically powerful than before. If so, how and why have business actors risen to such dominance?

At least it is safe to say that at the turn of the 1990s, business communities in Finland and in the rest of the West found themselves in a significantly better position than ten years earlier. The fall of the Soviet Union and the end of the Cold War at the turn of the 1990s signified the victory of the free market economy practically worldwide. An important factor contributing to the success of capitalism has been the lack of serious rivals in the realm of ideas since the collapse of communism (Bernhagen, 2005). As far as market ideology can be identified with corporate interests and values, business has fared well during the last couple of decades. However, it would 
be an overstatement to claim that business controls the general atmosphere. While business definitely enjoys a favourable climate of ideas, the state of affairs may be temporary. It can be undermined, for instance, by economic crises or corporations' misconduct and scandals, or completely overturned in the future by a change in general political and societal values (Fuchs, 2007; Smith 2000).

The particular value of an historical perspective is, then, to inform the ongoing academic and public debate on the power of business about its past evolution. This, in turn, facilitates more grounded judgements about their current state, too. Last but not least, historians can help to overcome oversimplifications about the political power of business and to illuminate the temporal nature of the phenomenon: It has fluctuated in the past and probably will continue to do so in the future. 
References:

Anastasiadis, S. (2006). Understanding Corporate Lobbying on Its Own Terms. Nottingham: University of Nottingham.

Bernhagen, P. (2005). The Political Power of Business: Structure and Information in Public Policymaking. (Dissertation), Trinity College, Dublin.

Blyth, M. (2002). Great Transformations: Economic Ideas and Institutional Change in the Twentieth Century. Cambridge: Cambridge University Press.

Boréus, K. (1994). Högervåg: Nyliberalismen och kampen om språket $i$ svensk debatt 1969-1989. (Dissertation), Stockholm: Tiden.

Boswell, J., \& Peters, J. (1997). Capitalism in Contention: Business Leaders and Political Economy in Modern Britain. Cambridge: Cambridge University Press.

Carey, A. (1995). Taking the Risk out of Democracy: Propaganda in the US and Australia (A. Lohrey Ed.). Sydney: UNSW Press.

Denham, A., \& Garnett, M. (1998). British Think-tanks and the Climate of Opinion. London - Bristol: UCL Press.

Dicey, A. V. (1905). Lectures on the Relation between Law \& Public Opinion in England during the Nineteenth Century. London: Macmillan.

Eley, G. (2002). Forging Democracy: The History of the Left in Europe, 1850-2000. Oxford: Oxford University Press.

Eloranta, J., \& Ojala, J. (2005). Converta - A Finnish Conduit in the East-West Trade. In J. Eloranta, \& J. Ojala (Eds.), East-West Trade and the Cold War (pp. 169198). Jyväskylä: University of Jyväskylä.

Fones-Wolf, E. (1995). Selling Free Enterprise: The Business Assault on Labor and Liberalism, 1945-60. Champaign: University of Illinois Press.

Frenander, A. (1999). Debattens vågor: Om politisk-ideologiska frågor $i$ efterkrigstidens svenska kulturdebatt. Göteborg: Institutionen för idé- och lärdomshistoria, Univ.

Friedman, G. (2008). Labor Unions in the United States. Retrieved from EH.net website: http://eh.net/encyclopedia/labor-unions-in-the-united-states

Fuchs, D. (2007). Business Power in Global Governance. Boulder: Lynne Rienner Publishers. 
Hayek, F. (1949). The Intellectuals and Socialism. The University of Chicago Law Review, 16(3), 417-433.

Hillman, A. J., Keim, G. D., \& Schuler, D. (2004). Corporate Political Activity: A Review and Research Agenda. Journal of Management, 30(6), 837-857.

Jacques, P. J., Dunlap, R. E., \& Freeman, M. (2008). The Organisation of Denial: Conservative Think Tanks and Environmental Scepticism. Environmental Politics, 17(3), 349-385.

Jensen-Eriksen, N. (2007). Läpimurto: Metsäteollisuus kasvun, integraation ja kylmän sodan Euroopassa 1950-1973. Helsinki: Suomalaisen Kirjallisuuden Seura.

Jensen-Eriksen, N. (2013). Capitalism under attack: Economic elites and social movements in postwar Finland. Manuscript submitted for publication.

John, R. R., \& Phillips-Fein, K. (Eds.). (2016). Capital Gains: Business and Politics in Twentieth-Century America. Philadelphia: University of Pennsylvania Press.

Julkunen, R. (2001). Suunnanmuutos:1990-luvun sosiaalipoliittinen reformi Suomessa. Tampere: Vastapaino.

Kervinen, E. (2006). Ajatuspajakokeilun opetukset: Poliittisia kysymyksiä käsittelevien think tank -prosessien kokeilu. Helsinki: Oikeusministeriö.

Kipping, M. (2003). Business-Government Relations: Beyond Performance Issues. In F. Amatori \& G. Jones (Eds.), Business History around the World (pp. 372-393). Cambridge: Cambridge University Press.

Koroma, J. (2015). Suomalaisten hyvinvointia rakentamassa: Teollisuuden Keskusliiton historia. Helsinki: Suomalaisen Kirjallisuuden Seura.

Kuisma, M. (2004). Kahlittu raha, kansallinen kapitalismi: Kansallis-Osake-Pankki 1940-1995. Helsinki: Suomalaisen Kirjallisuuden Seura.

Kuisma, M. (Ed.). (2008). Kriisi ja kumous: Metsäteollisuus ja maailmantalouden murros 1973-2008. Helsinki: Suomalaisen Kirjallisuuden Seura.

Kärrylä, I. (2016). Kansallinen etu demokratian rajoituksena: Suomalaisten työnantajien retoriikka 1960- ja 1970-lukujen yritysdemokratiakeskustelussa. Historiallinen aikakauskirja, 114(4), 445-457.

Lamberg, J.-A. (1999). Taloudelliset eturyhmät neuvotteluprosesseissa: Suomen kauppasopimuspolitiikka 1920-1930-luvulla. Helsinki: Suomen tiedeseura.

Lanzalaco, L. (2008). Business Interest Associations. In G. Jones \& J. Zeitlin (Eds.), The Oxford Handbook of Business History (pp. 293-315). Oxford: Oxford University Press. 
Lawton, T., McGuire, S., \& Rajwani, T. (2013). Corporate Political Activity: A Literature Review and Research Agenda. International Journal of Management Reviews, 15(1), 86-105.

Mansner, M. (1984). Suomalaista yhteiskuntaa rakentamassa: Suomen työnantajain keskusliitto 1940-1956. Helsinki: Teollisuuden kustannus.

Mansner, M. (1990). Suomalaista yhteiskuntaa rakentamassa: Suomen työnantajain keskusliitto 1956-1982. Helsinki: Teollisuuden kustannus.

McCluskey, J. J., \& Swinnen, J. F. M. (2010). Media Economics and the Political Economy of Information. In D. Coen, W. Grant, \& G. Wilson (Eds.), The Oxford Handbook of Business and Government (pp. 643-662). Oxford: Oxford University Press.

McGann, J. (2007). Think Tanks and Policy Advice in the United States: Academics, Advisors and Advocates. Abingdon, Oxon: Routledge.

Micklethwait, J., \& Wooldridge, A. (2004). The Right Nation: Conservative Power in America. New York: Penguin Press.

Millward, R. (1997). The 1940s Nationalizations in Britain: Means to an End or the Means of Production? The Economic History Review, 50(2), 209-234.

Mitchell, N. J. (1997). The Conspicuous Corporation: Business, Public Policy, and Representative Democracy. Ann Arbor: The University of Michigan Press.

Möttölä, K., Bykov, N. O. \& Korolev, I. S. (Eds.). (1983). Finnish-Soviet Economic Relations. London: Macmillan.

Nycander, S. (2002). Makten över arbetsmarknaden: Ett perspektiv på Sveriges 1900tal. Stockholm: SNS förl.

Okkonen, V. (2013). Elinkeinoelämän yhteiskunnallinen aktivismi politiikan muutoksen taustavoimana 1970-luvulta 1980-luvulle. Historiallinen aikakauskirja, 111(3), 293-306.

Paavonen, T. (2005). Special Arrangements for the Soviet Trade in Finland's Integration Solutions - A Consequence of Finland's International Position or Pursuit of Profit? In J. Eloranta \& J. Ojala (Eds.), East-West Trade and the Cold War (pp. 153-168). Jyväskylä: University of Jyväskylä.

Phillips-Fein, K. (2009). Invisible Hands: The Businessmen's Crusade against the New Deal. New York - London: W. W. Norton.

Phillips-Fein, K., \& Zelizer, J. E. (Eds.). (2012). What's Good for Business: Business and American Politics since World War II. Oxford: Oxford University Press. 
Pihkala, E. (1999). The Political Economy of Post-War Finland, 1945-1952.

Scandinavian Economic History Review, 47(3), 26-48.

Rich, A. (2004). Think Tanks, Public Policy, and the Politics of Expertise. Cambridge: Cambridge University Press.

Sassoon, D. (1997). One Hundred Years of Socialism: The West European Left in the Twentieth Century. London: Fontana.

Shaffer, B. (1995). Firm-level Responses to Government Regulation: Theoretical and Research Approaches. Journal of Management, 21(3), 495-514.

Skippari, M. (2005). Evolutionary Patterns in Corporate Political Activity: Insights from a Historical Single Case Study. (Dissertation), Tampere: Tampereen teknillinen yliopisto.

Smith, M. A. (2000). American Business and Political Power: Public Opinion, Elections, and Democracy. Chicago: The University of Chicago Press.

Stedman Jones, D. (2014). Masters of the Universe: Hayek, Friedman, and the Birth of Neoliberal Politics. Princeton: Princeton University Press.

Stenlås, N. (2001). The Rise of Political Activism in Scandinavian Big Business 19001950. In H. Byrkjeflot (Ed.), The democratic challenge to capitalism: Management and democracy in the Nordic countries. Bergen: Fagbokforlaget.

Sutela, P. (2005). Finnish Trade with the USSR: Why Was It Different? BOFIT Online 2005(7).

Tarkka, J. (2002). Uhan alta unioniin: Asennemurros ja sen unilukkari EVA. Helsinki: Otava.

Toninelli, P. A. (2000). The Rise and Fall of Public Enterprise: The Framework. In P. A. Toninelli (Ed.), The Rise and Fall of State-owned Enterprise in the Western World (pp. 3-24). Cambridge: Cambridge University Press.

Useem, M. (1984). The Inner Circle: Large Corporations and the Rise of Business Political Activity in the U.S. and U.K. New York: Oxford University Press.

Vogel, D. (1989). Fluctuating Fortunes: The Political Power of Business in America. New York: Basic Books.

Vogel, D. (1996). Kindred Strangers: The Uneasy Relationship between Politics and Business in America. Princeton: Princeton University Press.

Waterhouse, B. (2014). Lobbying America: The Politics of Business from Nixon to NAFTA. Princeton - Oxford: Princeton University Press. 
Wilks, S. (2013). The Political Power of the Business Corporation. Cheltenham: Edward Elgar Publishing.

Wilson, G., \& Grant, W. (2010). Business and Political Parties. In D. Coen, W. Grant, \& G. Wilson (Eds.), The Oxford Handbook of Business and Government (pp. 191-207). Oxford: Oxford University Press.

Wuokko, M. (2013). Layers of Disunity: The Presidential Politics of Finnish business, 1981-1982. Scandinavian Journal of History, 38(5), 612-635.

Wuokko, M. (2016). Markkinatalouden etujoukot: Elinkeinoelämän valtuuskunta, Teollisuuden keskusliitto ja liike-elämän poliittinen toiminta 1970-1980-lukujen Suomessa. (Dissertation), Helsinki: Helsingin yliopisto. 